\title{
The accessibility, use, fruition and enrichment of immobile cultural heritage A review of legislation in Slovenia, Croatia and Italy
}

\author{
Katharina Zanier, University of Primorska, Faculty of Humanities \\ and Institute for the Protection of Cultural Heritage of Slovenia
}

Prispevek predstavlja temeljne razlike v poudarkih varstva kulturne dediščine v Sloveniji, na Hrvaškem in v Italiji. Pomembne razlike se kažejo že v ustavah omenjenih držav, pri čemer je v Sloveniji poudarjen koncept ohranjanja kulturne dediščine, medtem ko se na Hrvaškem koncept ohranjanja kulturne dediščine neposredno povezuje z njeno uporabo, v Italiji pa z njeno obogatitvijo.

Ključne besede: kulturna dediščina, zakonodaja, dostopnost, raba, premična/nepremična dediščina

There are some basic discrepancies between the heritage legislatures of Slovenia, Croatia and Italy. There are important differences in the very constitutional documents; in Slovenia, the concept of preserving cultural heritage is stressed, while Croatia relates the concept of preservation of cultural heritage directly to its use, in Italy, this concept is related to the enrichment of cultural heritage.

Keywords: cultural heritage, legislature, accessibility, fruition, mobile/immobile cultural heritage

\section{Introduction}

T here are some basic discrepancies between the heritage legislatures of Slovenia, Croatia and Italy. There are important differences in the constitutional documents; in Slovenia, the concept of preserving cultural heritage is stressed (Constitution of Republic of Slovenia, Article 5: the state is responsible for the "conservation of natural resources and cultural heritage"; Article 73: "everyone is obliged by the law to preserve natural landmarks and cultural monuments. The state and local communities take care of natural and cultural heritage."), while Croatia relates the concept of preservation of cultural heritage directly to its use (cf. Article 2 and 52 of the Constitution of the Republic of Croatia); in Italy, this concept is related to the enrichment of cultural heritage (cf. Article II7 of the Constitution of the Republic of Italy). There are substantial differences in the rights and responsibilities regarding the ensured accessibility, use, fruition and enrichment of cultural heritage, exhibited in the legislature documents and related financial mechanisms of the states in question. In this respect, clear directions are of crucial importance particularly in the field of archaeological heritage, which rarely has features facilitating its direct use, understanding and fruition. General guidelines are specified in several international contracts and documents, particularly the Council of Europe Framework Convention on the Value of Cultural Heritage for Society, the Lausanne document (The ICOMOS Charter for the Protection and Management of the Archaeological Heritage), the ICOMOS Charter on Cultural Routes and the ICOMOS Charter for the Interpretation and Presentation of Cultural Heritage Sites.

We survey the legislature of the above-mentioned countries, particularly the fields, relevant to the conditions for the fruition of immobile 
cultural heritage. The articles were selected according to broader terms, such as the ownership of cultural heritage, mandatory maintenance, accessibility, terms of use, possibility of fruition, enrichment, management, financing and means for the implementation of measures for the protection, maintenance and enrichment of cultural heritage. Based on the general guidelines, specified in the Constitution of the Republic of Slovenia (Articles 5 and 73), the principles related to the accessibility, use, fruition and enrichment of immobile cultural heritage are defined in the Cultural Heritage Protection Act (Slov. "Zakon o varstvu kulturne dediščine" - ZVKD-I with amendments $\left.{ }^{r}\right)$. In Croatia, basic regulations regarding the accessibility and use of cultural heritage is specified in the Act on the protection and preservation of cultural goods (Zakon o zaštiti i očuvanju kulturnih dobara). In Italy, the area is regulated by the "Cultural Heritage and Landscape Code" (Codice dei beni culturali e del paesaggio $^{2}$ ). We aim to point towards certain deficiencies in the legislature, due to which several consequences occur - perhaps most notably, that the ZVKD-I does not imply any mechanisms for securing public budget funds for the financing of investments into the cultural heritage.

\section{Legislature}

\section{Slovenia}

Based on the guidelines of the Constitution of the Republic of Slovenia (Articles 5 and 73), the provisions regarding the accessibility, use, fruition and enrichment of immovable cultural heritage are defined in the Cultural Heritage Protection Act (ZVKD-I and amendments).

\section{Ownership}

In practice it has been shown that ownership of immovable cultural heritage is decisive in securing accessibility and possibilities of fruition, since in accordance with Article 54 of ZVKD-

Cf. Jelka Pirkovič and Borut Šantej, Pravno varstvo nepremične kulturne dedišcine v Sloveniji (Ljubljana: ZVKDS, 2012).

2 Cf. Maria Alessandra Sandulli, ed., Codice dei beni culturali e del paesaggio (Milano: Giuffre Editore, 2012).
I, monuments must be accessible to the public in proportion to the capacities of the owner or landowner. Otherwise, the possibility of exercising the pre-emption right and, exceptionally, expropriation is envisaged, in both cases by the authority that proclaimed the monument,

Based on Article 62 of the ZVKD-I, the state, the province or the municipality, have and can exercise pre-emptive right on monuments.

The state has a pre-emptive right on monuments of national importance and on immovable property in the influential area of a real monument of national importance, if so determined in the proclamation act.

The province or municipality that has declared the monument has a pre-emptive right on monuments of local importance; on real estate in influential areas of a monument of local importance, if so determined in the decree; in case of unused pre-emptive right of the state, as well as on a monument of national importance and on real estate in the influential area of a real monument of national importance (if so determined in the decree) located within the territory of that province or municipality.

A pre-emptive beneficiary may transfer pre-emptive rights to a third party if it improves conservation and public availability thereby ensuring such use, which is consistent with the social significance of the monument.

The pre-emptive right is excluded if the owner sells a thing from the first or second paragraph of this article to his/her spouse, relative or relative in a linear, adoptive or adoptive parenthood, adopted or adopted person or a public body whose founder is a state, province or municipality.

According to Article 63 of the ZVKD-I, property rights on real estate can be withdrawn against compensation or compensation in kind; expropriation is permissible if a monument or its protected values are endangered and if their preservation cannot be achieved otherwise. Interference with the right to property ownership must be proportionate to the public benefits that result in expropriation. The expropriation 
for monuments of national importance is proposed by the Government and for monuments of local importance the competent authority of the province or municipality that declared the monument. The expropriation must be carried out in the manner and in accordance with the procedure prescribed in the act governing the expropriation and restriction of the property right in the spatial planning, that is, in the main, in accordance with Articles 92-II4 of the Spatial Planning Act.

In the event that inspectors carry out inspection measures that remain unpaid by taxpayers, the state, province or municipality that proclaimed the monument obtains a legal mortgage on the property that was the subject of the measure (Article 42 of the ZVKD-I).

Special provisions also apply to small or movable archaeological finds which are transferred after processing to the care of state and authorized museums, where their accessibility guaranteed is in principle. According to Articles 6, 26, 53 and 135 of the ZVKD-I, the owner of movable archaeological remains, which are legally determined to be heritage, is the state. Disposal of archaeological finds that have been unlawfully excavated or otherwise illegally obtained from archaeological sites in the territory of the Republic of Slovenia or have been legally excavated and illegally retained is prohibited. A monument owned by the state, province or municipality that is an archaeological find or archaeological site or is insured under special regulations or international treaties to which the Republic of Slovenia is party may not be disposed of (Article 6 ZVKD-I).

\section{Maintenance}

Accordance to Article 38 of the ZVKD-I, owners must protect their monuments in proportion to their abilities. The Institute for the Protection of Cultural Heritage may, by decision, order owners to implement part or all of the implementation of certain measures for the implementation of the protection in proportion to the abilities of the owner, taking into account the benefits and benefits of the inheritance. The ability of the owner and the benefits and benefits referred to in this Article shall be assessed in the context of taxable property or taxable income. In the event of an unjustified failure to comply with this decision, the Office may itself carry out or organize measures of protection, requiring the owner to reimburse the proportionate part of the costs. In order to reimburse costs, the state, province or municipality that financed measures of protection has the right to claim a legal action against the owner. In doing so, the owner cannot list the burdens due to the increased security costs arising from the abandonment of security and regular maintenance.

If, during inspection, the inspector in charge of heritage finds that due to improper maintenance, handling or use of a monument or national treasure, or due to the omission of due care, there is risk of damage, they may prohibit such conduct or use and order to ensure protection (Article 117 of the ZVKD-I). If the inspector finds that there is an imminent danger of damage or damage to the immovable monument or national wealth has already occurred, they shall determine the measures and the time limit within which such risk or damage must be eliminated. If the inspected party fails to take appropriate measures, they will order that works be carried out at the expense of the taxpayer (Article 116 of the ZVKD-I).

Inspection measures are carried out at the expense of the taxable person in case of unauthorized interventions into registered heritage. If a taxpayer does not reimburse the funds for the implementation of the measure, the state, province or municipality that proclaimed the monument acquires a legal mortgage on the real estate subject to this measure (Article 42 of the ZVKD-I).

If a non-maintained monument or object threatens the property, health and life of people, traffic, adjacent objects or its surroundings, building inspection measures may also be in place (see Building Construction Act). 


\section{Accessibility}

For certain monuments, the act in the proclamation determines the obligation of public accessibility of the monument (Article I3 ZVKD-I). According to Article 54 of the ZVKD-I, monuments must be accessible to the public in proportion to the capacities of the owner or proprietor. If it is not possible in other ways to ensure the accessibility of the monument in accordance with the decree, the immovable property right may be withdrawn against compensation or compensation in kind according to Article 63 (see above).

The owner or proprietor of the monument must always allow the authorized person of the Institute for the Protection of Cultural Heritage to document and research the monument, after prior notice to the owner or landowner, also on enclosed land and in buildings, except in residential areas. If the owner or other person does not allow this, the authorized person has the right to carry out these activities with the assistance of the police (Article 55 of the ZVKD-I).

According to Article 58 of ZVKD-I, "immovable monuments are marked in order to improve public access. Labelling is carried out when this is not contrary to the benefits of protection and other public benefits"; in the event of an armed attack monuments are also marked based on ratified treaties (the Hague Convention). Regulations on the marking of stationary cultural monuments stipulate that each monument be marked with a monument's name in order to be better recognized. The designation of the monument is a signboard on the facade of a monument or a similar suitable place (vertical "marker element A"), a lower level monument (horizontal "marker element B") is marked with a floor board, in an exceptional case the board, upgraded with additional information ("marking element C"), but this type of marking usually does not replace the first two marking elements, mainly complementing them when the monument is not clearly recognizable (cultural landscape, archaeological site). Exceptionally, no particular archaeological or other monuments are designated, where the act of proclamation so provides, and this is necessary because of the manner of protecting the monument or its parts. All the signs on the board are in Slovene.

In the areas of municipalities where Italian and Hungarian are also used as the official languages, the inscriptions should be in these languages as well, but they should not be more pronounced than the inscriptions in Slovene. In addition, the inscriptions can also be in English. They are formally subordinate to official languages in Slovenia.

An additional mandatory element for cultural monuments is the sign of the Convention for the Protection of Cultural Property in the Event of Armed Conflict.

The UNESCO-listed monuments and monuments of European significance shall be marked in accordance with international acts determining their status.

The graphic elements of the labelling, the implementation and the quality of graphic elements and the standards for the complete implementation of the labelling of stationary cultural monuments of national and local importance are given in the Handbook for the Marking of Stationary Cultural Monuments.

\section{Management}

The owner or proprietor must ensure the management of the monument in accordance with the act of proclamation directly or by entrusting it to a manager. The manager must have all the monuments and all the monumental areas protected under the international treaties to which the Republic of Slovenia is party. The proclamation act can also be foreseen by the controller for other areas. The authority issuing the act on the proclamation of the monument area can manage the site on its own; for this purpose they must establish a public institution or entrust the monument management to a public institution established for the purpose of managing monuments and sites, or entrust the management to a natural person or a legal person under the law govern-

Ministry of Culture, Priroćnik za oznaćevanje nepremićnih kulturnih spomenikov (Ljubljana: Ministry of culture RS, 2010). 
ing public-private partnership. The management of the monument and the monument area is carried out on the basis of a management plan (Article 59 of the ZVKD-I).

"If the manager finances the restoration and maintenance with their own resources and assumes other burdens of risk, the authority which issued the act, concludes a concession contract with the manager for a period commensurate with the financial inputs and the manager's risks." (paragraph 6 of the article 59 ZVKD-I).

Management plan is a document defining the strategic and implementation guidelines for the overall preservation of the monument or site and the way in which its protection is implemented. A management plan should be adopted for all monuments and sites with a manager. According to the law, the management plan is prepared by the manager with the expert assistance of the institution and is adopted by the body that adopted the act on the proclamation of the monument, that is, the government or the ministry responsible, as a monument of national importance and the representative body of the province or municipality for a monument of local importance.

The management plan must contain the following: an overview of cultural values that should be specifically preserved and developed, a vision of protection and development, strategic and implementation objectives of management, provisions relating to the management structure and measures for protection against natural and other disasters, an action plan with a financial framework, in particular to ensure accessibility and management of the visit, indicators and the manner of monitoring implementation, and a deadline for the validity of the plan, the manner of updating and changing the plan.

In the case of joint management of several territorial or content-related monuments, a single management plan may be adopted for all monuments" (Paragraph 4 of Article 60 of the ZVKD-I).

If the site is coincides with an area protected under the regulations on nature conserva-

\section{tion, the management plan shall be adopted in agreement with the ministry responsible for the preservation of nature. In its prepa- ration, the organization responsible for na- ture conservation participates. (Paragraph 5 of Article 60 of the ZVKD-I).}

The management plan for the area of a single monument and nature protection is adopted by the government on the proposal of both ministers (in the fields of culture and nature). The government also appoints an area manager. The operator must be professionally qualified in both areas. The minister may conclude a contract with the manager of the single insurance area to transfer a part of the public tasks referred to in Article 84 of the ZVKD-I with the exception of public authorizations (Article 6I) to the manager.

Among the tasks of the ZVKDS is to cooperate with the managers of monuments in the preparation of proposals for the management plan (Article 84 of ZVKD-I).

\section{Finance}

In accordance with ZVKD-I, funds are provided in the budget of the Republic of Slovenia to cover the costs of preliminary research under Article 34, costs for co-financing the programs for reconstruction of monuments on the basis of Article 35, compensation costs under Article 39, investments of public funds on the basis of Article 40 and costs for the exercise of a pre-emptive right on the basis of Article 62 of this Act. ${ }^{4}$ According to Article 63, the government may consider monuments of national importance, but the competent authority of the province or municipality for monuments of local importance suggests expropriation against compensation or compensation in kind (see above).

Furthermore, ZVKD-I provides for special mechanisms for financing protection measures in the context of compensatory and compensatory measures. According to Article 3I, it is envisaged that the minister responsible for culture

4 See also Zala Koželj, Financiranje kulturne dedišcine v izbranih evropskih državah (Ljubljana: MA thesis, University of Ljubljana, 2013), $53-54$. 
may issue a cultural consent permit allowing the survey and removal of a monument or registered immovable heritage other than an archaeological site, even subject to the imposition of a compensatory measure, which may include the payment of an amount or the financing or the implementation of measures for the preservation or revitalization of another monument of comparable significance. In accordance with Article IIs, the inspector may, in the event of unauthorized interventions in archaeological remains, heritage or monuments, determine the implementation of alternative measures for the public benefit carried out within the framework of the public service of protection (in the case of unauthorized interference in archaeological remains, the implementation of the measure of protection of the archaeological site of comparable significance in the case of unauthorized interference in a registered heritage or monument, the intervention is carried out to preserve or revitalize a registered heritage or monument of comparable significance).

In accordance with the Act on the Provision of Funds for Certain Emergency Programs of the Republic of Slovenia in Culture, the budget of the Ministry responsible for culture provides funds for the gradual implementation of the program for the most endangered and of the highest quality cultural heritage facilities. ${ }^{6}$ The annual financial plan is prepared by the ministry responsible for culture, as a rule on the basis of a public tender or a public call. Individual projects are financed entirely from the state budget in cases of ownership or the founding of the state. Other projects are co-financed from the state budget in the amount of $50 \%$ of the value, unless otherwise specified in the program or project. In the event of a change of purpose or disposal of an object co-financed from

5 The new Law on the provision of funds for certain urgent programs of the Republic of Slovenia in culture is under consideration: https://www.dz-rs.si/wps/portal/Home/deloDZ/zakonodaja/iz-

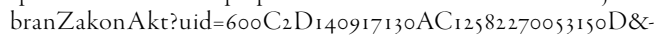
$\mathrm{db}=$ pre_zak\&mandat=VII (date of access: 1.5.2018).

$6 \quad$ Koželj, Financiranje kulturne dedišcine, 54-56. the state budget, the state's input in real value is returned to the state budget.

Other pieces of Slovenian legislature may come to some extent in order to provide funds for the implementation of cultural activities and measures of revitalization in areas of cultural heritage, e.g. the Act Regulating the Realisation of the Public Interest in the Field of Culture (ZUJIK). Public interest for culture is realized by the state and local communities independently or they are set up for the implementation of individual tasks by public funds or a public agency (Article 22 ZUJIK, cf. the Resolution on the National Program for Culture 2014-2017). The state and local communities provide public means to public funds and public agencies in accordance with regulations in the field of public funds, public agencies and public finance regulations for indirect budget users (Article $23 \mathrm{ZU}$ JIK; cf. the Public Fund of the Republic of Slovenia for Cultural activities).

When it is necessary in the public interest to provide public cultural goods in a permanent and undisturbed fashion, it is provided directly by the state or the local community, or by establishing a public institution in the field of culture (Article 26 ZUJIK). Public funds for the financing of public institutions are provided by their founders or co-founders. Furthermore, public institutions are financed from non-public sources (Article 3i ZUJIK).

The ministry responsible for culture, finances cultural programs and projects in the public interest for culture on the basis of ZUJIK.

Direct calls to public institutions, public funds and public agencies in the field of culture are used to finance operations that are in accordance with Articles 23 and 3I of ZUJIK. Public calls are used in cases where it is possible to clearly define the artistic, cultural and political criteria that must be met by a public cultural program or a cultural project for financing from public funds.

Public tenders are used in cases where it is possible to determine in advance the criteria for evaluating and evaluating proposals for cultur- 
al projects or programs, and those projects evaluated higher.

A public cultural program is cultural activity that, in terms of content and scope, is complete and carried out by a cultural performer whose founder is not the state or a local community; its operation is in the public interest to the extent that it is funded by the state or the local community in a comparable way as a public institution (Article 56 ZUJIK). The state or local community shall enter into a contract with a public cultural program contractor on the basis of a public tender or a public call. Normally, the contract is concluded for several years (Article 57 of ZUJIK).

In addition, financial synergies for the provision of funds are also theoretically possible for cultural heritage through donations in the field of tax legislation.

Pursuant to Article 142 of the Personal Income Tax Act, residents may require that up to $0.5 \%$ of assessed personal income tax be allocated for the financing of political parties and representative trade unions and for the financing of generally useful purposes, among them cultural ones. According to special regulations, beneficiaries of grants are set up to carry out those activities as non-profit activities and to whom, pursuant to a special law, they have been granted a special status or it was determined that their activity is in the public interest for the purpose of performing this activity. $\mathrm{V}$ skladu $\mathrm{z} 2$. členom Uredbe o namenitvi dela dohodnine za donacije za upravičence se ne štejejo rezidenti pravne osebe, ki so jih ustanovile ali katerih člani so pravne osebe javnega prava. On the proposal of the minister responsible for finance, the Government determines the list of beneficiaries annually, which is published in the Official Gazette of the Republic of Slovenia. The taxpayer may at any time submit a request for the allocation to the tax authority.

Pursuant to Article 59 of the Corporate Income Tax Act, a taxable person who is a legal entity of domestic and foreign law resident in the

Koželj, Financiranje kulturne dedišcine, 60.
Republic of Slovenia or a company or association of persons, including a civil-law company under foreign law, without legal personality (Article 3) may claim a reduction in the tax base for the amount of payments in financial means and in kind for various purposes, including cultural ones, for payments to residents of Slovenia and residents of the EU and EEA Member States, established under the special regulations for the performance of those activities, as of non-profit activities up to an amount equal to $0.3 \%$ of the taxable income of the taxable person's taxable period, but not exceeding the amount of the tax base of the tax period. The taxpayer may apply an additional reduction in the tax base up to an amount corresponding to $0,2 \%$ of the taxable income of the taxable person's taxable period, the amount of cash and in-kind payments for cultural purposes and for such payments to voluntary associations established for the protection against natural and other disasters, acting in public interest for these purposes, but up to the amount of the tax base. ${ }^{8}$

Moderate financial benefits for the implementation of activities in the field of the protection and preservation of cultural heritage also arise from the Value Added Tax Act, on the basis of which cultural services are directly linked to goods, including those carried out by public institutions and others, from states of a recognized cultural institution exempt from value added tax (Article 42, paragraph 13); the cultural services provided for in Article 69 of the Rules on the Implementation of the Value Added Tax Act also provide for the protection of cultural heritage. These services are exempted from VAT on the basis of prior notification, even if they are provided by subjects with the status of a society acting in the public interest in the field of culture or other persons with acquired status of activity in the public interest in the field of culture, provided certain conditions are met.

Pursuant the Inheritance and Gift Tax Act, such a tax is deductible if it is a gift or an inheritance that has the status of a cultural mon-

$8 \quad$ Koželj, Financiranje kulturne dediš̌ine, 59-60. 
ument, provided that the donated or inherited cultural monument is not disposed of before the expiration of 10 years, that a cultural monument is accessible to the public or that it is intended for the implementation of cultural activities (Article Io). Under the Property Tax Act, the transfer of immovable property that has the status of a cultural monument is also exempt from tax, provided that the cultural monument is accessible to the public or is intended for the implementation of cultural activities.' In both cases, however, it is not required that funds that have not been paid for the tax are invested in the preservation and maintenance of the monument, so the benefits for the monuments are at least partly questionable.

\section{Croatia}

Basic acts on accessibility in fruition of cultural heritage are covered by the Act on the protection and preservation of cultural goods (Zakono zaštiti i očuvanju kulturnih dobara).

\section{Ownership}

In the Republic of Croatia, possible expropriation of cultural heritage is in the interest of the state (Article 4I of the Act on the protection and preservation of cultural goods), if there is risk of damage or destruction of heritage, and the owner does not have the opportunity or interest to ensure the implementation of all measures of protection and conservation, a way to ensure the carrying out of archaeological research and excavations or the implementation of technical protection measures on cultural goods, unless it is possible to guarantee the accessibility of cultural heritage to the public. Expropriation may be complete or partial. Preparatory works and temporary seizure may be carried out in order to expropriate the cultural heritage, in accordance with the regulations on expropriation. The expropriation procedure is initiated on the proposal of the competent authority. The expropriation of cultural heritage is carried out in the manner prescribed by the Law on Expropriation and Set-

9 Koželj, Financiranje kulturne dedišcine, 58. tlement of Compensation (Zakon o izvlaštenju i odredivanju naknade).

When public funds are invested in the protection and preservation of the immovable cultural heritage, property right is created on this property for the benefit of the investor (Article 42 of the Act on the protection and preservation of cultural goods).

The owner intending to sell the cultural heritage must initially offer it to the Republic of Croatia, the county, the City of Zagreb, the city or municipality of the area in which the cultural heritage is located (Article 37 of the Act on the protection and preservation of cultural goods).

Much like in Slovenia, archaeological movable finds are property of the state (Article 19 of the Act on the protection and preservation of cultural goods).

\section{Maintenance}

The competent authority prepares documentation for the protection and preservation of cultural heritage and continuously monitors its state; at least once every five years, it produces a report on the state of heritage. The Minister of Culture prescribes the forms of the report on the state of affairs and the procedure for determining the state of cultural goods (Articles $5 \mathrm{I}^{-} 53$ of the Act on the protection and preservation of cultural goods).

Pursuant to Article 20 of the Act on the protection and preservation of cultural goods, the owner of cultural heritage must treat it with due respect and, above all, protect and regularly maintain it, implement measures of protection, immediately report any changes in cultural heritage, injuries or destruction, and the disappearance to competent authorities, authorize professional and scientific research, technical and other recording, as well as the implementation of technical protection measures and make the public accessible.

By issuing any decision, the competent body defines measures for the protection of cultural heritage. If the owner fails to implement the measures specified within a certain time limit, 
this measure will be carried out by the competent body at the expense of the owner.

The costs of preserving and maintaining cultural heritage and technical protection measures are borne by the owner. If maintenance of cultural heritage or the restoration, conservation or implementation of technical protection measures require extraordinary costs beyond regular maintenance costs and the revenue or other benefits of the owner, they have the right to apply for compensation for extraordinary expenses. Extraordinary costs are decided by the Ministry of Culture and the funds are provided in the state budget (Article 22 of the Act on the protection and preservation of cultural goods).

If the owner fails to act in accordance with the law thereby endangering cultural heritage, the mayor of Zagreb or the mayor of the area in which the cultural heritage is located, may, by a decision of the competent authority, determine the appointment of the temporary custodian of that heritage. The temporary guardian is obliged to implement the protection measures laid down by the competent authority on the account and the cost of the owner. The compensation for the work of the temporary guardian, as well as the cost of the implemented measures, must be settled by the owner (Article 32 of the Law on Ownership and Other Real Rights and Article 3I of the Act on the protection and preservation of cultural goods).

\section{Accessibility 2}

The owner of certain cultural heritage must allow its accessibility to the public (Article 20 of the Act on the protection and preservation of cultural goods).

In Croatia, a disc-shaped plate is envisaged for marking immovable cultural heritage and facilities in which collections of cultural goods are located. The way, the place of marking, as well as removing the label, insofar as the heritage loses its cultural heritage, is determined by the competent conservatory department of the Ministry of Culture (cf. Pravilnik o označavanju nepokret- nib kulturnih dobara i objekata u kojima su smještene zbirke kulturnih dobara).

\section{Fruition}

The competent authority (i.e the regional conservation department of the Ministry of Culture) decides on the purpose and method of using the immovable or movable cultural heritage, based on the previously obtained opinion of the mayor of Zagreb, mayor or municipal mayor. In order to change the purpose of cultural heritage, the owner is obliged to obtain prior approval from the competent authority (Article 34 of the Act on the protection and preservation of cultural goods). Legal entities and natural persons cannot start performing an economic activity in a space that is located within a stationary cultural heritage or a protected cultural and historical whole without the prior approval of the competent authority.

Article 43 of the Act on the protection and preservation of cultural goods regulates concessions for the use of immovable cultural heritage in public ownership for commercial purposes in accordance with the Law on Concessions. The concession is issued on the basis of a public bid. For the cultural heritage owned by the Republic of Croatia, the procedure is carried out by the Ministry of Culture, the heritage owned by the county, the City of Zagreb, and the cities and municipalities by their competent bodies. The concession is issued for a certain period, but not longer than for 99 years. The Decree on the concession also contains measures for the protection and preservation of cultural heritage, as prescribed by the competent authority, and the ways in which they are carried out by the concessionaire. The concession is paid for the benefit of the state budget or budget mayor, Zagreb, towns or municipalities according to the ownership of the cultural heritage.

Furthermore, according to Article II 4 , for all natural and legal persons who carry out an economic activity in immovable cultural heritage, the payment of a contribution, known as 
the monumental annuity, is envisaged (see below: Financing).

\section{Management}

Pursuant to Article 96 of the Act on the protection and preservation of cultural goods, the Republic of Croatia, the City of Zagreb, the towns and municipalities may establish institutes for the management of cultural heritage and the implementation of protection and conservation measures or entrust this task to another legal person. Funds and foundations can be created to preserve the cultural heritage.

Finance

In accordance with the Act on the protection and preservation of cultural goods (Articles 22 and 108 ), the owner or proprietor of cultural heritage, even if they are not the user, provides the means for its maintenance and maintenance.

Article rog of the Act on the protection and preservation of cultural goods also provides that funds for the protection and preservation of cultural heritage shall be guaranteed: a) from the state budget; b) from the county budget or the City of Zagreb, towns or municipalities, namely the preventive heritage and cultural heritage located in the county, the City of Zagreb, towns or municipalities, and in its entirety for the heritage of local importance under Article 17 of this Act; c) grants, compensation for concessions, records and funds; d) other sources.

The protection and preservation of the cultural heritage owned by the Republic of Croatia is financed from the state budget funds, as are the implementation of the national program for the protection and preservation of cultural heritage, extraordinary costs of maintaining cultural heritage, urgent measures of protection and conservation and compensation to owners due to the restriction of ownership rights.

National budget provides finance for projects of protection, conservation, restoration, presentation and maintenance of cultural heritage, in practice financed through calls from the Ministry of Culture. The sources are: a) a fixed amount of the state budget, b) $40 \%$ of all funds collected by the system of monument annuity, c) long-term loans for long-term reconstruction projects with a special social goal.

Funds from the regional and local self-government budget are used for the protection and preservation of the cultural heritage in their possession, for emergency measures, for the heritage of local importance, as well as for co-financing the national protection program.

For units of local and regional government, funding sources are: a) municipal, city and county budgets; b) $60 \%$ of the total amount of the annulment fee collected in the area of the local self-government unit. This resource is exploited by those cities and municipalities in which there are protected entities, and the cumulative resources must be invested in the cultural heritage.

Article II 4 specifically regulates budget revenues based on the use of cultural property as a direct and indirect monumental rent. ${ }^{\text {I0 }}$ Supervision over the payment of monument rent is made by the tax administration.

The statutory annuity is obligatory for natural and legal persons for the purposes of collecting the funds necessary for the protection and preservation of cultural heritage or for the implementation of the national program for the protection of cultural heritage, the amount of which is prescribed by decrees of cities and municipalities. This is compensation paid by economic operators for the pursuit of economic activities in, on or from a cultural heritage. There is therefore a dual system for determining the monument annuity. Monument rent is mandatory for natural and legal persons taxable on income or profit, but performing an economic activity in immovable cultural heritage, which is protected individually or in the area of the cultural and historical whole. Indirect monument rent is mandatory for natural and legal persons provided they perform the activities prescribed, regardless of the area or space in which this activity is performed (Article in 4.a of the Act

Io Cf. Jadran Antolović, Spomenicka renta: od teorije do hrvatske prakse Monument annuity: from theory to croatian practice (Zagreb: Ministarstvo kulture Republike Hrvatske, 2006). 
on the protection and preservation of cultural goods Act on the protection and preservation of cultural goods). It is thus collected on two bases: on the basis of the square meter of the space used and on the basis of $0.05 \%$ of the income of individual economic activities. Funds annually amount to over 200 million kuna. ${ }^{\mathrm{II}}$

\section{Italy}

In Italy protection of cultural heritage is regulated by the "Cultural Heritage and Landscape Code" (Codice dei beni culturali e del paesaggio ${ }^{\mathrm{I}}$ ).

\section{Ownership}

Movable and immovable cultural heritage found underground or in the sea is owned by the state (Article 9I).

Pursuant to Articles 53 and 54 of the " Cultural Heritage and Landscape Code ", certain categories of publicly owned heritage comprise a cultural state property (demanio culturale) and are inalienable, that is, real estate and areas of archaeological interest, real estate proclaimed monuments of national importance, collections of museums and galleries and libraries, as well as other cultural heritage of the deceased author, older than 50 years, until it was possibly confirmed in the process of verifying the cultural interest (for the procedure of checking the cultural interest, see Article I2).

The Ministry and regional and local self-governments have a pre-emptive right to entire cultural heritage, even if the inheritance has been disposed of without payment or for the exchange (Article 60).

The Ministry may perform expropriation of cultural heritage in the public interest and against payment (Article 95), as well as the expropriation of surrounding facilities and areas for the needs of the renovation of monuments, the provision of views and a decent environment, and the improvement of the possibilities

I I Maja Oven, Katharina Zanier, Ivica Pleština, Josip Višnjić and Vesna Bradamante, Poročilo o primerjavi zakonodaje in konservatorske prakse varstva kulturne dediščine v Sloveniji in Hrvaški (Ljubljana - Zagreb: unpublished report ZVKDS - HRZ, 2015), 42.

I2 Maria AlessandraSandulli, ed., Codice dei beniculturalie del paesaggio. of enjoyment and accessibility (Article 96). The Ministry may also perform expropriation of real estate for carrying out interventions of archaeological interest (Article 97).

\section{Maintenance}

Public and private owners and holders of cultural heritage are obliged to ensure the preservation of this heritage (Article 3I); according to the legal definition, conservation consists of research, prevention, maintenance and conservation-restorative interventions (Article 30). The consent of the competent body of the Ministry of Culture (or Sopritendenza), which defines the required conditions of intervention for the purpose of granting a tax deduction (Article 3I), must be obtained for all conservation operations. The Ministry may co-finance such operations in the amount of half the cost incurred or even in full amount, if interventions of special importance are implemented on cultural heritage in public use (Article 35).

The Ministry (Soprintendenza) may also require owners to implement measures for the preservation of cultural heritage within a specified time limit or directly implement them at the expense of the owner; if the interventions are particularly important or are implemented on cultural heritage in public use, the ministry may finance them partially or in full (Articles 32-34).

The Ministry takes care of the needs of maintaining state-owned cultural heritage, even if it is used by other administrations or entities (Article 39). Conservation and restoration on cultural heritage owned by regional and local self-governments are, in principle, regulated on the basis of previous programming agreements (Article 40).

\section{Accessibility}

Publicly-owned cultural heritage is intended for public use and enjoyment by the company, in accordance with the needs of protection and institutional use (Article 2).

For the immovable cultural heritage in private ownership, which was the subject of conser- 
vation and restoration interventions, partially or completely financed by the Ministry, it is necessary to provide public access in the manner specified in the agreement concluded between the ministry and the owner upon the approval of the contribution Articles 34 and 35.

The cultural heritage in private ownership, which was declared extremely important by the decision of the Ministry, must also be accessible to the public: the method is coordinated by the owner and the supervisory conservator (soprintendente) (Article I04).

Use

Ministry, regional and local self-governments can allocate the cultural heritage with their disposal to the application against payment of a fee (Article I06).

\section{Fruition}

The "Cultural Heritage and Landscape Code" defines "cultural institutions" and "cultural spaces" intended for enjoying cultural heritage, such as museums, libraries, archives, archaeological sites and archaeological parks and monument complexes. The Code therefore contains the official definition of archaeological park, which is "an area marked by important archaeological remains with a coexistence of historical, landscape or environmental importance and which is regulated as an open-air museum" (Article ror).

In the framework of the mentioned "institutions and cultural spaces”, the state, regional and local self-governments and all other public institutions are obliged to ensure access to and enjoyment of cultural heritage (Article IO2).

\section{Enrichment}

Enrichment of cultural heritage means the implementation of activities aimed at promoting knowledge of cultural heritage and ensuring the best conditions for public use of heritage and enjoyment of it in accordance with its protection (Article 6). Cultural heritage enrichment activities form the foundation and stable organization of resources, structures and networks, or the dis- position of professional capabilities, financial and technical resources. Within the enrichment activities, private entities can participate and can be launched on a public or private initiative; enriching cultural heritage on a private initiative is a socially beneficial activity (Article III).

The state, regional and local self-governments ensure the enrichment of cultural heritage in the mentioned "institutions and cultural spaces". To this end, the state, through the ministry, regional and local self-government, concludes agreements at the regional level for the purpose of harmonization and timing of enrichment activities, under which agreements private entities may also participate. Agreements may, with the consent of the interested parties, also concern the cultural heritage of private ownership. However, public entities may make special arrangements with cultural societies active in the promotion of cultural heritage knowledge (Article ir2).

The private property and cultural heritage enrichment activities and structures can be used on a private initiative by public support from the state, regional and local self-governments (Article iI3).

The Ministry, regional and local self-governments, together with universities, define uniform quality enrichment standards and regularly update them; and the ministry adopts them by decree. Entities that manage enrichment activities are obliged to respect accepted quality standards (Article II 4 ).

\section{Management}

Heritage enrichment activities on a public initiative can be managed directly or indirectly. Direct management can be undertaken by internal organizational structures with appropriate professional, organizational, financial and administrative capabilities.

Indirect management: a) institutions, foundations, societies, consortia, companies or other entities established by public administrations, holders of cultural heritage, take over the management of these activities through direct award; 
or b) management is granted to third parties through a public tender. It is also possible to include both management methods. A service contract is concluded that defines quality levels and powers of direction and control. The allocation of management of enrichment activities may relate to the allocation for the use of the cultural heritage itself, which is the object of enrichment (Article iIs).

Additional services for visitors (publishing and sale of publications, information and animation for children, guided tours, catering, exhibitions and events, promotional activities, etc.) may be managed in "institutions and cultural spaces" (Article iI7).

\section{Finance}

As already mentioned (see: Maintenance), the Ministry may co-finance interventions of preservation of cultural heritage in private ownership, in part or in full, if interventions are of special importance and are implemented on cultural heritage in public use (Articles 34 and 35) .

Otherwise, the Ministry may make contributions to cover the costs of loans for conservation measures that the owners of cultural heritage have decided to carry out, which is also the case for conservation and restorative interventions on buildings of contemporary architecture, whose artistic value was recognized by the competent supervisory conservator (soprintendente) (Article 37).

It should be noted that contributions from Articles 35 and 37 have been suspended in 20122015 for the purposes of balancing public finances.

The " Cultural Heritage and Landscape Code" (Article iro) defines income on the basis of entrance fees to state-owned "institutions and premises of culture" (and on the basis of additional services for visitors) as budget revenues for carrying out interventions for their conservation and for implementation expropriation and purchase of cultural heritage, including on the basis of a pre-emptive right. Receipts from entrance fees to institutions and premises owned by oth- er public entities (and on the basis of additional services for visitors) are intended to increase and enrich the cultural heritage.

Article 120 of the "Cultural Heritage and Landscape Code" envisages the sponsorship of cultural heritage, that is, any form of contribution by a private entity to carry out activities in the field of the protection and enrichment of cultural heritage in order to promote their own name, brand, image, activity or product. Such promotion must be in accordance with the artistic and historical characteristics, the appearance and dignity of the cultural heritage, which must be defined in the sponsorship contract.

Further agreements with banking foundations, which are socially useful goals in the field of art and cultural heritage according to the statute, are foreseen for the purpose of coordinating interventions for the enrichment of cultural heritage and the allocation of related financial burdens (Article I2I).

\section{Discussion and conclusions}

Comparing legislatures regarding the accessibility, use and possible fruition of immobile cultural heritage in Slovenia, Croatia and Italy reveals considerable differences, addressed in this chapter in relation to conditions, particular to the archaeological heritage.

Ownership is of particular importance for the public use of the cultural heritage. This is particularly true of immobile archaeological heritage, whose preservation in situ is characteristically in conflict with the functional use of land by its owners: it can easily happen that an owner of a property with an archaeological monument, destined to be preserved in situ, is imposed with restrictions regarding its use; on the contrary, preservation of architectural heritage does not hinder the use of land property.

In all three countries, disowning property owners (in reasonable cases) or exercising the right of pre-emption is a foreseeable measure in Croatia and Italy, disowning applies to the procedures of archaeological research as well. In Italy, disowning the owners of objects and areas 
located in the near vicinity of cultural heritage applies as well, if required for the needs of landscaping. This was critically reviewed, ${ }^{13}$ since the purpose of landscaping does not require permanent ownership but only temporary occupation (occupazione) against compensation for the time of landscaping procedures; however, such in instrument is not implied in the "Cultural Heritage and Landscape Code" - but it is in the case of archaeological research (Article 88).

In all three countries, mobile archaeological finds are state property according to the law. In Italy, this extends to the immobile archaeological heritage; according to Italian legislature, (archaeological) goods under the ground are exempted from ownership rights. In practice, in Italy, too, access to these remains is ensured in the disownment and pre-emption act.

In Italy, the procedure of keeping record of cultural heritage is also different in regards to its ownership. In the case of public ownership, cultural heritage is automatically any cultural good of a deceased author, which is older than 50 years. The ministry can conduct surveys of cultural interest - prompted by the owners themselves; if no such interest is established, a cultural good is exempted from the protection regime (Cultural Heritage and Landscape Code, Article 12 ). Real estate and objects in private ownership are required to be proclaimed objects of cultural interest, which needs to be established according to its special meaning (cf. Articles Io and I2). For this particular reason, cultural heritage is mainly in public property in Italy.

The responsibility of maintenance of the monuments by their owners is reduced according to their capabilities in the Slovenian legislature; no such proportional share is expressed in either Italian or Croatian legislature, which tasks the owners with equal responsibilities in the preservation of cultural heritage in their ownership. In order to make these responsibilities bearable, considerable subsidies are availa-

I3 Gabriele Torelli, "Lacquisizione sanante nel codice dei beni culturali e del paesaggio." Aedon Rivista di arti e diritto on line 2 (2016), http://www.aedon.mulino.it/archivio/2016/2/torelli.htm (date of access: 1.5 .2018 ). ble in both countries. Furthermore, in Italy, cultural heritage whose renovation has been funded by the ministry must be at least partially accessible to public, which reflects the concept of a quid pro quo - public use for public funds.

It seems particularly beneficial, that in Croatia the state of cultural heritage is surveyed at least once every five years, for which a special form is available (Articles 5I through 53 of the Cultural Heritage Protection and Preservation Law - Zakona o zaštiti i očuvanju kulturnih dobara), which would be a good idea in Slovenia as well, monitoring is an immensely important aspect of preventive action and integral preservation of heritage; regular maintenance would greatly reduce the costs of heritage maintenance.

As in the case of maintenance, public accessibility also relates to the owner's capabilities in Slovenia - provided it is implied in the promulgation act. It is only mandatory to allow access to authorized personnel of the Institute for the Protection of Cultural Heritage of Slovenia (ZVKDS) for the purposes of documenting and research. It is also mandatory to tag the monument in a prescribed manner, provided it is not contrary to the benefits of protection. ${ }^{\text {I4 }}$

There is no such concept of relative owners' responsibility regarding access in Croatian legislature, according to which all owners of cultural heritage must allow its public accessibility. Just like in Slovenia, a unified tagging system is devised (Pravilnik o označavanju nepokretnih kulturnih dobara i objekata u kojima su smještene zbirke kulturnih dobara).

Italian legislature exhibits important differences regarding access: only publicly owned cultural heritage is intended for public use, while the public accessibility of privately owned cultural heritage must be based on either its special meaning or the public funds used for its renovation. This difference relates to the instrument of disownment of cultural heritage, which is used particularly for the purpose of public accessibility.

I4 Ministry of Culture, Prirocnik za oznaćevanje nepremicnih kulturnih spomenikov (Ljubljana: Ministry of culture RS, 2010). 
According to the definition in the ZVKDI (Article 3), the use of cultural heritage means "perpetual or temporary activity, conducted in heritage, by it or in any other relation to it, influencing it in the process or using its cultural value and social meaning." Furthermore, Article 44 prohibits the use of a monument's image or name for commercial purposes without the consent of the owner, who is entitled to proportionate compensation. Provisions in the paragraph IV.2 (the Use) apply to mobile heritage, too. It follows, that there is no special legal framework in Slovenia, which regulates this particular issue, apart from specific regulations regarding the use of monuments, as stipulated in the protection regimes.

This particular set of issues is very meticulously addressed in Croatia, where the use of heritage or the change of its purpose for the purpose of commercial activities within an object of immobile cultural heritage requires a special approval of the conservation department of the Ministry of culture; conducting commercial activities in an object of immobile cultural heritage is subject to special taxation. Similarly, there is a procedure of issuing concessions for the use of publicly owned immobile cultural heritage for the purposes of commercial exploitation against concession fee - yet this is still fairly limited. ${ }^{15}$ One such case of a concession was issued to diving centres with the exclusive rights to conduct underwater tours of archaeological sites along the Adriatic coast (Cavtat, Mljet, Žirje, Pag, Rab, Umag), named "Underwater Museums" (Podmorski muzeji). ${ }^{16}$ It appears that in this case a fairly demanding activity of promoting knowledge about cultural heritage was provided in a most efficient way, because the concession fees represent a budget income, while the contractors took it upon themselves to conduct the activities in an efficient and high-quality manner with regards to the preservation of heritage, as defined in the concession contract.

is Cf. the list of local concessions for cultural heritage: http://servisi. fina.hr/regkonc/trazi.do (date of access: 1.5.2018).

16 Rukavina T., Muzej u dubokom plavetnilu, 2009: http://www. min-kulture.hr/default.aspx?id=4998 (date of access: 1.5 .2018 ).
In Italy, too, concession fees for the use of cultural heritage are defined in the legislature; the fee is divided between the state and the local authorities; this practice is fairly well established in the case of temporary use, such as in instances of public events etc.

Places of fruition of cultural heritage are defined; apart from museums and other institutions, related to mobile cultural heritage, the definition implies archaeological areas, archaeological parks and other monument complexes. There is also an official definition of an archaeological park, which is not available in Slovenia, meaning that the term applies to archaeological sites without distinction, even if archaeological remains are only minimally presented. The Italian official definition says an archaeological park is an area arranged as an open air museum, meaning that it offers visitors certain ways of enhancing knowledge about heritage.

Activities of promoting knowledge about heritage and providing the best conditions for the public use of heritage and its fruition (both of which fall within the definition of enriched heritage) are especially addressed in the Italian legislation, highlighting the importance of establishing stable networks, structures and resources, to which end agreements are concluded on the regional level to ensure sustained and coordinated action by all interested parties. The latter may be public legal entities or private entities; the enriched cultural heritage may be publicly or even privately owned, funding may also be public or private. It seems equally important that the Italian legislation provided for the process of defining norms and quality standards for the performance of activities of heritage enrichment.

It follows that in Italy, only activities of heritage enrichment and not entire objects of heritage per se become subject to management; heritage preservation may be the responsibility of its owner, but it can also be simultaneously allocated to a manager. It is clearly enough, such a method of assigning the management of individual segments of heritage allows the retention 
of its most sensitive section, i.e. the activities of preservation of cultural heritage, in the hands of the owner or holder, as well as differentiation of professional qualification requirements of a manager with regard to the tasks assigned.

Furthermore, the Italian legislature meticulously defines procedures of allocating management. The internal structures of a heritage holder can directly manage this heritage in a twofold manner: holders of cultural heritage can set up a legal entity, which is directly allocated the management of heritage, or a heritage manager can be selected through a public tender. The practice of legal entities in the form of large consortia or foundations has proven particularly successful, where the financial burden of the new entity is split into a larger number of founders and heritage holders, while the management of such a combined group proved to be more coordinated. An example at hand is e.g. the "Aquileia Foundation" (Fondazione Aquileia), established for the purpose of enrichment activities in the area of Aquileia, under the Regional Act (Legge Regionale $18 / 2006,{ }^{17}$ based on the Article iIs of the Codice dei beni culturali e del paesaggio) by the Ministry of Culture, the region of Friuli Venezia Giulia, the municipality of Aquileia, the province of Udine and the Gorizia archbishopric, which all co-finance the foundation.

In Croatia and Slovenia, the law provides that owners may entrust the management of heritage to another legal entity, while the selection process and the allocation is not defined in detail. However, the ZVKD-I provides that "in accordance with the act declaring a site, the body which issued the act may directly manage the monument site, setting up for that purpose a public institution, or entrusting the management of a public to an institution established for the purpose of managing monuments and sites, or entrusting the management to a natural or legal person under the law governing public-private partnership" (paragraph 3 of Article 59). This is clearly contrary to the provision that

i7 http://www.fondazioneaquileia.it/repository/download/lris 82006.pdf(date of access: 1.5.2018). the owners chose who may be entrusted with the management, since the body that issued the act is not necessarily the owner. We clearly need guidelines in the managers' selection process as well as in determining how to fund heritage management - and in the provision of quality standards. Major deficiencies were recorded e.g. in the management of the open air archaeological sites, which were comprehensively surveyed. ${ }^{\mathrm{I}}$

Quote: "In Slovenia we recorded 44 locations, where a number of shortcomings in the field of management were identified. The most evident is lack of basic maintenance and the consequential decay of the heritage, and, las but not least, the absence of interpretative contents, which would increase their availability in the broadest sense of the word." (Breznik 2014, Io6).

This brings us to the basic question, relevant for the ensuring of public access to cultural heritage and its fruition: the funding. In this respect, the movable and immovable cultural heritage is highly differentiated: in the case of national and authorized museums, intended for the fruition of cultural heritage, the funding is clearly regulated (ZUJIK). However, in the case of immovable cultural heritage the state budget provides for the implementation of specific measures for the protection and restoration ${ }^{20}-$ no doubt a prerequisite for any kind of fruition of cultural heritage -, but the enrichment activities are essentially neglected. In general, the absence of mechanisms which could provide the financial resources is a problem, since they could create revenues in the state budget, ${ }^{21}$ from which it would be possible to finance the planned pub-

I8 Cf. Andreja Breznik, Upravljanje arheoloskega parka v RS (Ljubljana: Doctoral Dissertation University of Ljubljana, 2012).

19 Andreja Breznik, "Vrednotenje arheoloških najdišč za upravljanje v obliki turističnega kompleksa arheološki park," Studia universitatis hereditati 2, no. $\mathrm{I}-2$ (2014): 106.

20 Koželj, Financiranje kulturne dedišcine, 54-56.

2 I It was expected to collect certain assets by unprecedented sale of state-owned monuments or monuments owned by municipalities (Article 6ZVKD-I), or in the context of countervailing (Article 3I ZVKD-I) and alternative measures (Article is ZVKD-I), or through compensation for devaluation (Article 4I), all of which cases involve emergency situations associated with at least partial loss of cultural heritage, and cannot, therefore, constitute a basic me- 
lic investments in cultural heritage. This reflects the general belief that the cultural heritage cannot be autonomously financed, thus automatically constituting little more than a burden.

The Codice dei beni culturali e del paesaggio (Article IIo) defines the benefits from entrance fees (and services for visitors) into the state-owned 'institutions and places of culture' as budgetary revenue for the implementation of their conservation and the expropriation or purchasing of cultural heritage, including on the basis of pre-emption rights. Earnings from for admission fees (and services for visitors) to institutions and facilities owned by other public entities are intended to increase and enrich the cultural heritage. Article 120 of the Codice dei beni culturali e del paesaggio provides sponsorship of cultural heritage, i.e. any form of contribution by a private entity to carry out activities in the field of protection and enrichment of the cultural heritage in order to promote their own name, trademark, image, activities or products. Such promotion must be in accordance with the artistic and historic properties, appearance and dignity of cultural heritage, which must be defined in the contract of sponsorship In Croatia, a most successful system of public funding was devised, not so much through concessions for the use of publicly owned cultural heritage as via monument rent..$^{22}$ In Italy, budgetary revenue is revenue arising from the sale of tickets and additional services for visitors in museums and other public spaces of culture, such as archaeological parks and monumental complexes. In Slovenia, the entrance fees to museums do cover a small part of the operating costs of museums, so it would be wise to ask ourselves whether it could be possible to establish a more efficient system. As for the case of archaeological sites with exhibited archaeological remains (archaeological "parks"), entrance is mostly free. Of course the concept of making entrance available to low income groups is not reproachable, but

chanism for ensuring the revenue from which it could be possible to finance relevant public investments.

22 Jadran Antolović, Spomenička renta. the question is whether such a system is sustainable in the long term, not to mention other paid services, which could generate the - as yet - virtually non-existent revenue.

Clearly enough, the tourism sector benefits from the cultural heritage and its protection the most; cultural and natural landscapes are by definition the core of touristic offer in a certain area. ${ }^{23}$ This is why an implementation of a monument rent of a sort would be logical - similarly as royalties are charged for the play of music in bars and restaurants. This would also formally reflect the exhibited economic importance of immovable cultural heritage for the development tourism, whereas state budget would benefit greatly in the field of cultural sector, which could provide an adequate financial basis for the investing of public funds into cultural heritage.

\section{Povzetek}

Prispevek predstavlja temeljne razlike v poudarkih varstva kulturne dediščine v Sloveniji, na Hrvaškem in v Italiji. Pomembne razlike se kažejo že v ustavah omenjenih držav, pri čemer je v Sloveniji poudarjen koncept ohranjanja kulturne dediščine, medtem ko se na Hrvaškem koncept ohranjanja kulturne dediščine neposredno povezuje z njeno uporabo, v Italiji pa z njeno obogatitvijo.

Bistvene razlike v določanju pravic in odgovornosti na področju zagotavljanja dostopnosti, uporabe, uživanja in obogatitve kulturne dediščine se izražajo tudi v področnih zakonodajnih dokumentih in s temi povezanih finančnih mehanizmih teh držav. Jasne usmeritve so bistvenega pomena prav na področju arheološke dediščine, saj ima ta redkokdaj takšne lastnosti, ki bi lahko neposredno omogočile njeno uporabo, razumevanje in uživanje. Splošno veljavne smernice za to področje so podane $\mathrm{v}$ različnih mednarodnih pogodbah in listinah. Predstavitev je namenjena prikazu določenih pomanjkljivosti na naši zakonodajni ravni, zaradi katerih nastajajo znatne posledice v praksi. Najbolj očitna je, da v samem Zakonu o varstvu kulturne dediščine niso predvideni mehanizmi za zagotavljanje državnih proračun-

23 Janez Planina, "Primarna in sekundarna turistična ponudba ter njune posebnosti," Turistićni vestnik 4 (1966): 161-164. 
skih prihodkov za financiranje sicer na več načinov predvidenega vlaganja javnih sredstev v kulturno dediščino.

\section{Summary}

There are some basic discrepancies between the heritage legislatures of Slovenia, Croatia and Italy. There are important differences in the very constitutional documents; in Slovenia, the concept of preserving cultural heritage is stressed, while Croatia relates the concept of preservation of cultural heritage directly to its use, in Italy, this concept is related to the enrichment of cultural heritage. There are substantial differences in the rights and responsibilities regarding the ensured accessibility, use, fruition and enrichment of cultural heritage, exhibited in the legislature documents and related financial mechanisms of the states in question. In this respect, clear directions are of crucial importance particularly in the field of archaeological heritage, which rarely has exhibits features facilitating its direct use, understanding and fruition. General guidelines are specified in several international charters and documents. We aim to point towards certain deficiencies in the legislature, due to which several consequences occur - perhaps most notably, that the ZVKD does not imply any mechanisms for securing public budget funds for the financing of investments into the cultural heritage.

\section{Bibliography}

\section{Sources on national legislature}

\section{Slovenia}

Pravilnik o izvajanju Zakona o davku na dodano vrednost (Uradni list RS, št. I4I/O6, 52/07, I20/07, 21/08, I23/08, I05/09, 27/IO, I04/IO, IIO/IO, 82/II, I06/II, I08/II, IO2/I2, 54/I3, 85/14 in 95/I4).

Pravilnik o označevanju nepremičnih kulturnih spomenikov (Uradni list RS, št. 57/II).

Resolucija o nacionalnem programu za kulturo 2014-20I7 (Uradni list RS, št. 99/13).

Resolucija o nacionalnem programu za kulturo 2018-2025 (Predlog: https://e-uprava. gov.si/drzava-in-druzba/e-demokracija/ predlogi-predpisov/predlog-predpisa. html?id=9158)
Pravilnik o vlaganju in reševanju zahtevkov za financiranje predhodnih arheoloških raziskav iz državnega proračuna (Uradni list RS, št. 93/14 in 73/16)

Uredba o namenitvi dela dohodnine za donacije (Uradni list RS, št. 30/07, 36/07 in $37 / 10$ ).

Zakon o davku na dediščine in darila (Uradni list RS, št. II7/06).

Zakon o davku na dodano vrednost (Uradni list RS, št. I3/II - uradno prečiščceno besedilo, I8/II, 78/II, 38/I2, 83/I2 in 86/I4).

Zakon o davku na promet nepremičnin (Uradni list RS, št. II7/06).

Zakon o davku od dohodkov pravnih oseb (Uradni list RS, št. I17/06, 56/08, 76/08, 5/09, 96/09, 110/09 - ZDavP-2B, 43/10, $59 / \mathrm{II}, 24 / \mathrm{I2}, 30 / \mathrm{I2}, 94 / \mathrm{I2}, 8 \mathrm{I} / \mathrm{I} 3$ in $50 / \mathrm{I} 4)$.

Zakon o dohodnini (Uradni list RS, št. I3/II uradno prečiščeno besedilo, 9/12 - odl. US, 24/12, 30/12, 40/12 - ZUJF, 75/12, 94/12, $52 / 13$ - odl. US, $96 / 13,29 / 14$ - odl. US in $50 / 14)$.

Zakon o Javnem skladu Republike Slovenije za kulturne dejavnosti - (ZJSKD) (Uradni list RS, št. 29/IO).

Zakon o uresničevanju javnega interesa za kulturo (Uradni list RS, št. 96/2002, I23/2006-ZFO-I, 7/2007 Odl.US: U-I35/04-II, 53/2007, 65/2007 Odl.US: U-I-276/05-II, 77/2007-UPBI, 56/2008, 94/2009 Odl.US: U-I-278/07-17, 4/2010, 20/20II, I00/20II Odl.US: U-I-210/10-IO, III/2OI3) (ZUJIK).

Zakon o varstvu kulturne dediščine

(Uradni list RS, št. I6/08, I23/o8, 8/II ORZVKD $39,90 / 12,111 / 13,32 / 16$ in $21 / 18$ - ZNOrg) (ZVKD-I).

Zakon o zagotavljanju sredstev za nekatere nujne programe republike Slovenije v kulturi (Uradni list RS, št. I 4/03 - uradno prečiščeno besedilo in 77/08).

\section{Croatia}

Pravilnik o označavanju nepokretnih kulturnih dobara i objekata u kojima su smještene 
zbirke kulturnih dobara (Narodne novine, broj $12 / 06$ ).

Zakon o izvlaštenju i određivanju naknade

(Narodne novine, broj 74/14).

Zakon o koncesijama (Narodne novine, broj I $43 / 12$ ).

Zakon o vlasništvu i drugim stvarnim pravima (Narodne novine, broj 91/96, 68/98, 137/99, 22/00, 73/00, I29/00, II 4/OI, 79/06, I41/06, I 46/08, 38/09, I53/09, I 43/12, I52/14).

Zakon o zaštiti i očuvanju kulturnih dobara (Narodne novine, broj 69/99, 151/03, ispravak 157/03, 87/09, 88/10, 6I/II, 25/I2, I36/I2, I57/I3, I52/14).

Italy

Codice dei beni culturali e del paesaggio (d. lgs. 22/OI/2004 n 42, G.U. 24/02/2004; d. lgs. 24 marzo 2006, n. 156; d. lgs. 24 marzo 2006, n. 157; d. lgs. 26 marzo 2008, n. 62; d. lgs. 26 marzo 2008 , n. 63; D.L. 3 I maggio 2014, n. 83; D.L. I9 giugno 2015, n. 78 ; L. 6 agosto 2015 , n. 125; D.Lgs. 7 gennaio 2016, n. 2).

International treatises

Council of Europe Framework Convention on the Value of Cultural Heritage for Society (Faro 2006): https://rm.coe. int $/ 1680083746$

The ICOMOS Charter for the Protection and Management of the Archaeological Heritage (Lausanne 1990): http://www. international.icomos.org/charters/arch_e. pdf

The ICOMOS Charter for the Interpretation and Presentation of Cultural Heritage Sites (Québec 2008): http://www. international.icomos.org/charters/ interpretation_e.pdf

The ICOMOS Charter on Cultural Routes (Québec 2008): http://www.icomos.org/ charters/culturalroutes_e.pdf

\section{References}

Antolović, Jadran. Spomenička renta: od teorije do hrvatske prakse / Monument annuity: from theory to croatian practice. Zagreb: Ministarstvo kulture Republike Hrvatske, 2006.

Breznik, Andreja. Upravljanje arheološkega parka v RS. Ljubljana: Doctoral Dissertation University of Ljubljana, 2012.

Breznik, Andreja. "Vrednotenje arheoloških najdišč za upravljanje v obliki turističnega kompleksa arheološki park." Studia universitatis hereditati 2, no. I-2 (2OI4): IOS-II7.

Koželj, Zala. Financiranje kulturne dediščine v izbranih evropskih državah. Ljubljana: Magister Dissertation University of Ljubljana, 2013.

Ministry of Culture. Priročnik za označevanje nepremičnih kulturnih spomenikov. Ljubljana: Ministry of culture RS, 20 Iо.

Oven, Maja, Katharina Zanier, Ivica Pleština, Josip Višnjić and Vesna Bradamante, Poročilo o primerjavi zakonodaje in konservatorske prakse varstva kulturne dediščine v Sloveniji in Hrvaški. Ljubljana - Zagreb: unpublished report ZVKDS HRZ, 2015.

Pirkovič, Jelka, and Borut Šantej. Pravno varstvo nepremične kulturne dediščine $\mathrm{v}$ Sloveniji. Ljubljana: ZVKDS, 2012.

Planina, Janez. "Primarna in sekundarna turistična ponudba ter njune posebnosti." Turistični vestnik 4 (1966): 16I-164.

Sandulli, Maria Alessandra, ed. Codice dei beni culturali e del paesaggio. Milano: Giuffre Editore, 2012.

Torelli, Gabreiele. "L'acquisizione sanante nel codice dei beni culturali e del paesaggio." Aedon Rivista di arti e diritto on line 2 (2016). http://www.aedon.mulino.it/ archivio/2016/2/torelli.htm. 